\title{
Radiační havárie jaderné elektrárny v České republice
}

\author{
Lucie Knödlová \\ Západočeská univerzita v Plzni, Fakulta právnická
}

\begin{abstract}
Anotace: Tato práce pojednává o řešení mimořádné bezpečnostní situace, která je představována jadernou havárií atomové elektrárny Temelín. Práce se $v$ úvodu zaměřuje na pojem radiační havárie, zabývá se jejími přičinami a následky. Dále práce zkoumá právní úpravu České republiky zabývající se řešením radiační události, a to od úrovně ústavní až po jednotlivé vyhlášky a individuální havarijní plány, a také se věnuje tématu omezení lidských práv $z$ důvodu mimořádné bezpečnostní situace. $V$ závěru práce pojednává o evropské a mezinárodní právní úpravě radiačních havárií a o Mezinárodní agentuře pro atomovou energii.
\end{abstract}

Klíčová slova: jaderná elektrárna, radiační havárie, mimořádná radiační událost, odezva na mimořádnou radiační událost, havarijni plánování

Abstract: This work is about dealing with an emergency security situation which represents a nuclear accident of the nuclear power plant Temelin. In the introduction The work focuses on the concept of radiation accident and deals with its causes and consequences. Thesis examines the legislation of the Czech Republic dealing with the solution 
of a radiation event from the constitutional level to individual decrees and individual emergency plans. The work also deals the issue of human rights restrictions due to an emergency security situation. The end of the thesis deals with European and international legislation on radiation accidents and the International Atomic Energy Agency.

Keywords: nuclear power plant, nuclear akcident, radiation emergency, response to a radiation emergency, emergency planning

\section{Úvod}

Tato práce se zabývá řešením nestandardní bezpečnostní situace, která je představována radiační havárií jaderné elektrárny v České republice. Jako model havárie s únikem radiace bude pro účely této práce sloužit jaderná elektrárna Temelín.

Cílem této práce je uvést do problematiky radiačních událostí, přičin jejich vzniku a zhodnotit dostatečnost české právní úpravy této nestandardní bezpečnostní situace, a to z pohledu ústavní úpravy, z pohledu zákonné úpravy a podzákonné úpravy. Dalším cílem je zhodnocení proporcionality omezení lidských práv a svobod z důvodu jaderné havárie za účelem ochrany osob a majetku a také vlivu evropské právní úpravy na právo vnitrostátní. V neposlední radě se práce zabývá vztahem práva mezinárodního a práva vnitrostátního v případě radiační havárie a také rámcem úpravy, který právo mezinárodní stanovuje pro právo vnitrostátní. 


\section{Definice jaderné havárie s uvolněním radiace, její př́ičiny a následky}

„Jaderná havárie $s$ uvolněním radiace neboli radiační havárie je událost, která vede nebo může vést $k$ překročení limitů ozáření a která vyžaduje zavedení neodkladných ochranných opatření pro obyvatelstvo, která by zabránila překročení nebo zhoršování situace z pohledu zajištění radiační ochrany."

Přičiny jaderné havárie $s$ uvolněním radiace jsou různorodé, obvykle jaderná havárie $v$ jaderné elektrárně vznikne $v$ momentě, kdy dojde $k$ porušení těsnosti obalu jaderného paliva $v$ aktivní zóně jaderného reaktoru, $\mathrm{k}$ úniku radioaktivních látek do chladiva či modulátoru, úniku radioaktivní směsi z primárního okruhu do reaktorového bloku nebo k úniku radioaktivní směsi z reaktorového bloku do okolí elektrárny. ${ }^{2}$

Pro účely této práce jsem si připravila modelovou situaci, při které by došlo k jaderné havárii s uvolněním značného množství radiace do okolí jaderné elektrárny Temelín.

Na území celé České republiky došlo k plošnému výpadku elektrické energie, $v$ jaderné elektrárně Temelín se spustily tři záložní dieselové generátory. Tyto

\footnotetext{
'Základní informace pro připad radiačni havárie jaderné elektrárny Temelín 20182019. Zpracoval: Útvar havarijní připravenosti ČEZ, a. s., a Útvar komunikace ETE ČEZ, a. s. Obsah byl schválen SÚJB, hejtmanem Jihočeského kraje a HZS Jihočeského kraje.

${ }^{2}$ Jaderné havárie. In: Jaderné elektrárny [online]. [cit. 14. 7 2019]. Dostupné z: <https:// www.jaderne-elektrarny.cz/jaderna-havarie/>
} 
generátory pohání chladicí zařizení, díky kterým je možné odvádět zbytkové teplo z jaderného reaktoru. $Z$ důvodu nedostatku paliva došlo k selhání dvou ze tři dieselových generátorů, následně došlo $k$ výpadku systémů, které odváději teplo z reaktoru. $V$ reaktoru začala nekontrolovatelně stoupat teplota a tlak. Při překročení 1000 stupňů Celsia se začaly urychlovat exotermické reakce. Reakcí zirkonia, které se nachází $v$ chladicích prutech, a vodní páry vznikl vodík a jiné látky (ve vysoké koncentraci je vodík vysoce hořlavá látka). Vodík se nahromadil $v$ horních částech elektrárny a došlo k explozi, která poškodila kontejnment, kde se nachází atomový reaktor, a vinou přehřátí a urychlení štěpení uranu začaly unikat radioaktivní nuklidy uranu. Naměřená radiace $v$ elektrárně dosahovala hodnot 5 rentgenů za hodinu, což odpovídá 100 rentgenům zubů za hodinu.

Tato modelová situace, označená jako mimořádná radiační událost, by spustila mechanismus odezvy na mimořádnou radiační událost, který stanový právní úprava, již se budu zabývat v další kapitole.

„Radioaktivní látky mohou být ve formě plynů nebo aerosolů odnášeny větrem do okolí jaderné elektrárny. Následně se mohou usazovat na budovách, pưdě, rostlinách, případně lidské pokožce nebo našich oděvech a v životním prostředí obecně. Tento proces nazýváme kontaminace. Tyto radioaktivní látky se do lidského organismu mohou dostat vdechnutím (tzv. inhalací) nebo konzumací kontaminovaných tekutin a potravin (tzv. ingescí) a způsobovat tak vnitřní 
(interní) ozáření. Radioaktivní látky usazené na povrchu terénu mohou způsobit vnější ozáření osob (tzv. ozáření z oblaku a depozitu).“3

„Jakým způsobem a v jaké koncentraci se budou radioaktivní látky šírit mimo jadernou elektrárnu, je především ovlivněno vlastním průběhem radiační havárie a počasím $v$ okamžiku úniku radioaktivních látek $a v$ období těsně po něm. Koncentrace radioaktivních látek a tím i míra ohrožení obyvatelstva radioaktivními látkami závisí na konkrétních meteorologických podmínkách a klesá s rostoucí vzdáleností od zdroje a časem od úniku radioaktivních látek."

V Československu došlo k havárii atomové elektrárny Jaslovské Bohunice v roce 1977 při doplňování jaderného paliva. Jednalo se o havárii 4. stupně (havárie bez vážnějšího vlivu na okolí), rozmontování a dekontaminace bude probíhat až do roku $2033 .^{5}$

\section{2 České právo a řešení mimořádné radiační události}

Tato část se zabývá řešením mimořádné radiační události z pohledu české právní úpravy od úpravy obsažené v ústavním zákoně až po jednotlivé vyhlášky. Zkoumá odezvu, kterou

\footnotetext{
${ }^{3}$ Základni informace pro případ radiační havárie jaderné elektrárny Temelín 2018-2019. Zpracoval: Útvar havarijní připravenosti ČEZ, a. s., a Útvar komunikace ETE ČEZ, a. s. Obsah byl schválen SÚJB, hejtmanem Jihočeského kraje a HZS Jihočeského kraje.

${ }^{4}$ Tamtéž.

${ }^{5}$ Jaderné havárie. In: Jaderné elektrárny [online]. [cit. 14. 7 2019]. Dostupné z: <https:// www.jaderne-elektrarny.cz/jaderna-havarie/>
} 
přináši zákonné a podzákonné právní předpisy na mimořádnou radiační událost.

\section{1 Ústavní zákon o bezpečnosti České republiky 110/1998 Sb.}

Při vzniku radiační havárie jaderné elektrárny dochází ke splnění základních kritérií, která jsou potřebná pro vyhlášení nouzového stavu, jehož vznik, vyhlášení a ukončení je podrobně uvedeno $v$ ústavním zákoně o bezpečnosti České republiky.

Dle tohoto ústavního zákona Ize vyhlásit nouzový stav z důvodu ohrožení značného rozsahu, které se týká vnitřního pořádku, bezpečnosti, života a zdraví, majetkových hodnot nebo životniho prostředí. Nouzový stav se vyhlašuje podle intenzity, územního rozsahu a charakteru situace. ${ }^{6}$

Nouzový stav může vyhlásit vláda nejdéle na dobu 30 dnů7 $v$ připadě živelných nebo ekologických pohrom či průmyslových havárii. Zároveň s vyhlášením nouzového stavu musí vláda vymezit, která práva stanovená ve zvláštním zákoně ${ }^{8}$ a $v$ jakém rozsahu se $v$ souladu $s$ Listinou základních práv a svobod omezují a které povinnosti a $v$ jakém rozsahu se ukládají. Podrobnější úpravu oprávnění vlády v době nouzového stavu uvádí krizový zákon. ${ }^{9}$

\footnotetext{
${ }^{6}$ Ústavní zákon o bezpečnosti České republiky 110/1998 Sb.

${ }^{7}$ Uvedená doba se může prodloužit jen po předchozím souhlasu Poslanecké sněmovny.

${ }^{8}$ Zákon č. 240/2000 Sb., o krizovém řizení a o změně některých zákonů (krizový zákon).

${ }^{9}$ Ústavní zákon o bezpečnosti České republiky 110/1998 Sb.
} 
Rozhodnutí o nouzovém stavu se zveřejňují v hromadných sdělovacích prostředcích a vyhlašují se stejně jako zákon. Účinnosti nabývají okamžikem, který se v rozhodnutí stanoví.

\subsection{Zákon č. 263/2016 Sb., atomový zákon}

Atomový zákon se zabývá především mírovým využíváním jaderné energie a ionizujícího záření, dále přestupky držitele povolení pro provoz jaderných zařizení a výkonem státní správy, která zajištuje kontrolu těchto zařizení.

Atomový zákon se vypořádává s řešením mimořádných radiačních událostí v části 2, hlava VIII. Zde jsou uvedena opatření ke zvládnutí situace související se vznikem radiační mimořádné události s cílem znovunabytí kontroly nad vzniklou situací a zabránění následkům vzniklé radiační mimořádné události. Jedná se zejména o požadavky na analýzu a hodnocení mimořádné radiační události, připravenost $k$ odezvě a povinnosti držitele povolení k provozu jaderného zařizení k zajištění připravenosti k odezvě, samotnou odezvu na radiační událost a nápravu jejích následků..$^{10}$ Ve věcech neupravených tímto zákonem se postupuje podle zákona o krizovém řízeni1 ${ }^{11}$ nebo podle zákona o integrovaném záchranném systému. ${ }^{12}$

Pro účely odstupňované připravenosti k odezvě na radiační mimořádnou událost se dle tohoto zákona radiační mimořádná událost zařazuje do kategorie radiační mimořádná událost

${ }^{10}$ Zákon č. 240/2000 Sb., o krizovém řizení a o změně některých zákonů (krizový zákon). ${ }^{11}$ Tamtéž.

${ }^{12}$ Zákon č. 239/2000 Sb., o integrovaném záchranném systému. 
prvního stupně, radiační nehoda nebo radiační havárie. Jednotlivé kategorie se liší dle zvladatelnosti vypořádání se s radiační událostí, dle vzniku a dle dopadu na obyvatelstvo. ${ }^{13}$

\subsection{Vyhláška č. 359/2016 Sb., o podrobnostech k zajištění zvládání radiační mimořádné události}

Tato vyhláška zpracovává příslušné předpisy směrnice Rady 2013/59/ EURATOM, kterou se stanoví základní bezpečnostní standardy ochrany před nebezpečím vystavení ionizujícímu záření, kterou se budu zabývat v kapitole evropského práva, a směrnice Rady 2014/87/ EURATOM, kterou se stanoví rámec Společenství pro jadernou bezpečnost jaderných zařizení.

Z hlediska probíraného tématu je tato vyhláška stěžejní, nebot' upravuje postupy a opatření $k$ zajištění připravenosti k odezvě na radiační mimořádnou událost a její pravidla. Dále stanovuje požadavky na zajištění připravenosti k odezvě v zóně havarijního plánování a požadavky na stanovení zóny havarijního plánování, kterou se budu zabývat níže. ${ }^{14}$

\subsubsection{Zóna havarijního plánování jaderné elektrárny Temelín}

Havarijním plánem se rozumí soubor opatření k likvidaci radiační nehody nebo radiační havárie a k omezení jejich

${ }^{13}$ Zákon č. 240/2000 Sb., o krizovém řizení a o změně některých zákonů (krizový zákon). ${ }^{14}$ Vyhláška č. 359/2016 Sb., o podrobnostech k zajištění zvládáni radiační mimořádné události. 
následků. Havarijní plán jaderné elektrárny Temelín se skládá z vnitřního a vnějšího havarijního plánu. Vnitřní havarijní plán je plán pro prostory jaderného zařízení nebo pracoviště, kde se vykonávají radiační činnosti. Vnější je plán pro oblast v okolí jaderného zařizení nebo pracoviště, kde se nachází zdroj ionizujícího záření, v niž se na základě výsledků rozborů možných následků radiační havárie uplatňuji požadavky z hlediska havarijního plánování a která se nazývá zóna havarijního plánování. ${ }^{15}$ Vnější a vnitřní havarijní plán jaderné elektrárny Temelín na sebe musí navzájem navazovat, nemohou být tvořeny bez propojení, které je důležitou podmínkou pro rychlé zvládnutí mimořádné radiační situace. Ověřování účinnosti a vzájemného souladu vnějšího a vnitřního havarijního plánu probíhá společným procvičením scénáře pro radiační havárie vzniklé na jaderném zařízení a jeho následném vyhodnocení.

„Vnější havarijní plán jaderné elektrárny Temelín je dokument Jihočeského kraje pro strategickou úroveň řizení. Obsahuje návrhy opatření k omezování následků radiační havárie na jaderné elektrárně Temelín a základní úkoly pro jejich provedení. Dokument slouží složkám integrovaného záchranného systému, orgánům veřejné správy a dotčeným subjektům ke zpracování vlastní prováděci dokumentace a $k$ připravě na záchranné a likvidační práce prováděné $v$ důsledku radiační havárie jaderné elektrárny Temelín."16 Opatření a činnosti

\footnotetext{
${ }^{15}$ Výpis z vnějšího havarijniho plánu pro zónu havarijního plánování JE Dukovany. In: Oficiální internetové stránky Kraje Vysočina [online]. 11. 2. 2005 [cit. 14.7 2019]. Dostupné z: <https://www.kr-vysocina.cz/vypis-z-vnejsiho-havarijniho-planu-pro-zonu -havarijniho-planovani-je-dukovany/d-854177>

${ }^{16}$ Vnějši havarijní plán jaderné elektrárny Temelín. In: Hasičský záchranný sbor České republiky [online]. [cit. 14. 7 2019]. Dostupné z: <https://www.hzscr.cz/clanek/vnejsi
} 
plánované ve vnějším havarijním plánu jsou pravidelně prověřovány cvičením. Za tímto účelem se $v$ pravidelných intervalech konají cvičení s názvem ZÓNA. Poslední cvičení proběhlo 10.-12. června 2019 s názvem ZÓNA 2019.

Zóna havarijního plánování jaderné elektrárny Temelín je prostor v okolí jaderného zařízení, kde se uplatňují požadavky na přípravu zavedení opatření na ochranu obyvatelstva. Stanovení ZHP schvaluje Státní úřad pro jadernou bezpečnost na základě návrhu provozovatele jaderného zařizení. Území ZHP je rozděleno na vnitřní a vnější část. Vnitřní část tvoři kruh o poloměru $5 \mathrm{~km}$ a vnější část tvoři mezikruži $5-13 \mathrm{~km} .{ }^{17}$ Pro území zóny havarijního plánování jsou plánována ochranná opatření k omezení ozáření osob při radiační havárii, kterými jsou neodkladná ochranná opatření zahrnující varování a informování obyvatelstva, ukrytí, jódovou profylaxi a evakuaci obyvatelstva a následná ochranná opatření zahrnující přesídlení, regulaci požívání radionuklidy kontaminovaných potravin, vody a krmiv. ${ }^{18}$

\section{Omezení lidských práv z důvodu jaderné havárie}

Základní lidská práva a svobody uvedené v ústavě a v Listině základních práv a svobod jsou neomezitelná. I když ústava a Listina základních práv počítají s neomezitelností těchto práv, u určitých situací může dojít k jejich kolizi, tato kolize

-havarijni-plan-jaderne-elektrarny-temelin.aspx>

${ }^{17}$ Přiloha: Obrázek č. 1.

${ }^{18}$ Základní informace pro připad radiační havárie jaderné elektrárny Temelín 20182019. Zpracoval: Útvar havarijní připravenosti ČEZ, a. s., a Útvar komunikace ETE ČEZ, a. s. Obsah byl schválen SÚJB, hejtmanem Jihočeského kraje a HZS Jihočeského kraje. 
se řeší testem proporcionality. Pomocí testu proporcionality dojde za určitého postupu k omezení jednoho práva ve prospěch druhého, tento postup zkoumá vhodnost, potřebnost a přiměřenost omezení daného základního lidského práva.

Radiační událost představuje takový stav, jehož nápravy by nemohlo být dosaženo bez omezení některých základních lidských práv. Jedná se o situaci, kdy dochází ke kontaminaci životního prostředí, a bez zavedení bezodkladných opatření není možné zabránit šiření kontaminace. Proto z hlediska vhodnosti, potřebnosti a přiměřenosti Ize přijmout taková opatření zahrnující omezení lidských práv či ukládání povinností, aby došlo k nápravě krizové situace a předešlo se jejímu zhoršení.

V případě radiační události a následného vyhlášení nouzového stavu je vláda oprávněna na základě krizového zákona omezit na nezbytně nutnou dobu a v nezbytně nutném rozsahu právo na nedotknutelnost osoby a obydlí při evakuaci osoby z místa, na kterém je bezprostředně ohrožena na životě nebo zdraví, dále vlastnické a užívací právo právnických a fyzických osob k majetku, pokud jde o nucené omezení práva vlastníka nebo uživatele z důvodu ochrany života, zdraví, majetku nebo životního prostředí, které jsou ohroženy krizovou situací, přičemž je za toto omezení poskytnuta přiměřená náhrada, a omezit svobodu pohybu a pobytu ve vymezeném prostoru území ohroženého nebo postiženého krizovou situací. ${ }^{19}$

${ }^{19}$ Zákon č. 240/2000 Sb., o krizovém řizení a o změně některých zákonů (krizový zákon). 
„Vláda je oprávněna v době trvání nouzového stavu nařídit evakuaci osob a majetku z vymezeného území, zakázat vstup, pobyt a pohyb osob ve vymezeném území nebo místech, ukládat pracovní povinnosti, pracovní výpomoci nebo povinnosti poskytnout věcné prostředky a je oprávněna nařídit bezodkladné provádění staveb, stavebních prací, terénních úprav nebo odstraňováni staveb anebo porostů za účelem zmírnění nebo odvrácení ohrožení vyplývajícího z krizové situace. ${ }^{\text {"20 }}$

\section{Evropské právo a řešení mimořádné radiační události}

Dne 1. 5. 2004 vstoupila Česká republika do Evropské unie, od tohoto dne se na ni začaly vztahovat právní předpisy Evropské unie. Důležitým dokumentem týkajícím se atomového práva je Smlouva o založení Evropského společenství pro atomovou energii (EURATOM), není to však jediný dokument týkající se této problematiky, existuji další právní předpisy, především práva sekundárního v podobě nařizení, směrnic či rozhodnutí, které se zabývaji problematikou atomového práva a také konkrétně řešením mimořádných radiačních situací.

\subsection{Smlouva o založení Evropského společenství pro atomovou energii}

Základním dokumentem v oblasti využivání jaderné energie a ionizujícího záření v Evropě je Smlouva o založení Evropského společenství pro atomovou energii (EURATOM). Smlouva

${ }^{20}$ Zákon č. $240 / 2000$ Sb., o krizovém řizení a o změně některých zákonů (krizový zákon). 
o Euratomu byla podepsána představiteli šesti zakládajících států (Francie, Německa, Itálie, Belgie, Lucemburska a Nizozemska) v Římě 25. 3. 1957 a vstoupila v účinnost dne 1. 1. $1958 .^{21}$

Hlavním cílem Euratomu bylo přispět k vytvoření podmínek nezbytných pro rychlé vybudování a růst jaderného průmyslu a nastavit mechanismy pro kontrolu možného zneužití jaderných materiálů. Prostředky pro dosažení tohoto cíle jsou formulovány v čl. 2 Smlouvy o Euratomu. Stručně Ize uvést podporu jaderného výzkumu, vytvoření jednotného jaderného trhu zajištujícího volný pohyb kapitálu a pracovníků, zajištění ochrany zdraví obyvatel a pracovníků se zdroji před účinky ionizujícího záření, zavedení mechanismu pro kontrolu nad tím, aby jaderný materiál nebyl zneužíván k jiným účelům, než pro které je určen. ${ }^{22}$

Od přijetí Smlouvy o Euratomu cíle a úkoly vymezené touto Smlouvou a prostředky k jejich dosažení zůstaly ve Smlouvě o Euratomu nezměněny, často se proto využívá extenzivní výklad některých ustanovení Smlouvy, a to tak, aby vyhovoval současným potřebám.

\footnotetext{
${ }^{21}$ Smlouva o Euratomu. In: Státni úřad pro jadernou bezpečnost [online]. [cit. 14. 72019 ]. Dostupné z <https://www.sujb.cz/evropska-unie/smlouva-o-euratomu-a-sekundarni -pravni-predpisy/smlouva-o-euratomu/>

${ }^{22}$ Evropské společenství pro atomovou energii - Euratom. In: Státni úřad pro jadernou bezpečnost [online]. [cit. 14.72019 ]. Dostupné z <https://www.sujb.cz/evropska-unie/ evropske-spolecenstvi-pro-atomovou-energii-euratom/>
} 


\subsection{Směrnice Rady 2013/59/EURATOM}

Právním základem pro vypracování sekundárních právních předpisů jsou články 31 a 32 Smlouvy o Euratomu.

Směrnice Rady 2013/59/EURATOM stanovuje základní bezpečnostní standardy ochrany zdraví osob, které jsou vystaveny profesnímu ozáření, lékařskému ozáření a ozáření obyvatelstva, před nebezpečím vyplývajícím z ionizujícího záření. Dále se vztahuje na každou plánovanou, existující nebo nehodovou expoziční situaci zahrnující riziko, které vyplývá z vystavení ionizujícímu záření a které nelze zanedbat z hlediska radiační ochrany nebo z hlediska ochrany životního prostředí s ohledem na dlouhodobou ochranu lidského zdraví. ${ }^{23}$

Směrnice stanovuje rámec pro havarijní připravenost zahrnující odezvu na havarijní situaci včetně havarijního plánování a zajištění okamžitých ochranných opatření. Tato opatření byla provedena do české právní úpravy vyhláškou č. 359/2016 Sb. o podrobnostech k zajištění zvládání radiační mimořádné události, ze dne 17. 10. 2016, kterou jsem se zabývala výše.

\section{Mezinárodní právo a řešení mimořádné radiační události}

Z hlediska mezinárodního práva se můžeme setkat s řešením mimořádných radiačních událostí pomocí úmluv, které se touto problematikou zabývají. Jedním s důležitých dokumentů je Úmluva o pomoci v případě jaderné nebo radiační nehody.

\footnotetext{
${ }^{23}$ Směrnice Rady 2013/59/EURATOM.
} 
Tato úmluva byla přijata v roce 1986 po radiační havárii atomové elektrárny Černobyl a stanoví mezinárodní rámec pro spolupráci mezi státy, které jsou stranami úmluvy, a Mezinárodní agenturou pro atomovou energii s cílem usnadnit okamžitou pomoc a podporu $v$ prípadě radiační nehody, jaderné havárie nebo mimořádné radiační události. ${ }^{24}$ Česká republika jakožto nástupnický stát České a Slovenské Federativní Republiky se považuje s účinností od 1. 1. 1993 touto Úmluvou být vázána.

\subsection{Mezinárodní agentura pro atomovou energii}

Mezinárodní agentura pro atomovou energii (IAEA) je rozsahem své činnosti a svým vlivem nejvýznamnější světovou organizací $v$ otázce dohledu a kontroly nad bezpečností jaderné energetiky. IAEA byla založena v roce 1957 jako mezivládní fórum zabývající se širokým spektrem otázek spojených s tehdy rychle se rozvijející jadernou energetikou. Hlavní aktivity Agentury spadají do oblastí bezpečnostních a verifikačních mechanismů, fyzické ochrany a rovněž vědy a technologického výzkumu. Zásadním úkolem Agentury je dohližet na implementaci tzv. dohod o bezpečnostních zárukách v jednotlivých státech. ${ }^{25}$

\footnotetext{
${ }^{24}$ Convention on Assistance in the Case of Nuclear Accident or Radiological Emergency. In: International Atomic Energy Agency [online]. [cit. 14.7 2019]. Dostupné z $<$ https://www.iaea.org/topics/nuclear-safety-conventions/convention-assistance-case -nuclear-accident-or-radiological-emergency>

${ }^{25}$ CKD. IAEA. In: Euroskop [online]. Záři 2018 [cit. 14.7 2019]. Dostupné z <https:// www.euroskop.cz/9137/sekce/iaea/>
} 
Pro minimalizaci dopadů jaderné nehody, havárie nebo mimořádné radiační události jsou nezbytné účinné vnitrostátní a celosvětové mechanismy odezvy. IAEA udržuje mezinárodní rámec připravenosti a odezvy na mimořádné radiační události a zároveň pomáhá udržovat a posilovat účinné mechanismy reakce na národní a mezinárodní úrovni. $V$ rámci těchto aktivit rozvíji bezpečnostní normy, směrnice a technické nástroje. ${ }^{26}$

\subsubsection{Mezinárodní stupnice hodnocení závažnosti jaderných a radiačních událostí}

Mezinárodní stupnice hodnocení závažnosti jaderných událostí (INES) byla v roce 1990 zavedena mezinárodními experty svolanými Mezinárodní agenturou pro jadernou energii (IAEA) a Agenturou pro jadernou energii Organizace pro ekonomickou spolupráci a rozvoj (OECD/NEA) s cílem oznamování bezpečnostní významnosti událostí v jaderných zařizeních. Od té doby byla INES rozšířena, aby splňovala rostoucí potřebu komunikace o významnosti jakékoliv události, která vyvolá radiační nebezpečí. ${ }^{27}$

Události jsou klasifikovány podle stupnice do sedmi stupňů: stupně 4-7 se nazývají „havárie“ a stupně 1-3 „nehody“. Události bez bezpečnostního významu jsou klasifikovány „pod stupnicí / stupeň 0“. Události, které nemají žádný

\footnotetext{
${ }^{26}$ Emergency preparedness and response. In: International Atomic Energy Agency [online]. [cit. 14. 7 2019]. Dostupné z <https://www.iaea.org/topics/emergency -preparedness-and-response-epr $\geq$

${ }^{27}$ Státní úřad pro jadernou bezpečnost. INES, mezinárodní stupnice hodnocení závažnosti jaderných a radiačních událostí, uživatelská příručka. Překlad INES: The International Nuclear and Radiological Event Scale User's Manual. Překlad vydán roku 2016. Připraveno v SÚJB, s. 9.
} 
bezpečnostní vztah $\mathrm{k}$ jaderné nebo radiační bezpečnosti, nejsou dle stupnice klasifikovány. Pro komunikaci s veřejností o těchto událostech byly každému stupni INES přiřazeny jasně odlišitelné zkrácené názvy. Dle rostoucí závažnosti jsou to: „anomálie“, „nehoda“, „vážná nehoda“, „havárie s místními následky“, "havárie s širšími následky“, „těžká havárie“ a „velmi těžká havárie“. 2829

Každá členská země IAEA je povinna v přesně stanoveném termínu o každé nehodě či havárii informovat koordinační centrum IAEA, které je ohodnotí určitým stupněm INES vždy podle jejího nejhoršího dopadu na okolní životní prostředí, na prostředí v objektu a jeho bezprostředním okolí.

\section{Závěr}

Mimořádná radiační událost je zvlášṫ závažná nestandardní bezpečnostní situace. Odezvu na tuto událost řeší česká zákonná úprava velmi pečlivě a s dostatečnou intenzitou. Od vyhlášení nouzového stavu až po havarijní plánování se setkáváme s postupy, které jsou předem připraveny a prísně kontrolovány, požadavky na tyto postupy jsou zakotveny v zákonné a podzákonné úpravě.

Z hlediska omezení lidských práv se setkáváme s proporcionalitou, tedy vyvážeností takovýchto omezení v zájmu včasného zvládnutí mimořádné radiační události a zabránění jejího šíření.

${ }^{28}$ Tamtéž, s. 14.

${ }^{29}$ Přiloha: Obrázek č. 2. 
Evropské právo přináši rámec úpravy atomového práva a také rámec s požadavky na zvládání mimořádných radiačních událostí a včasné odezvy na tyto situace. Podrobnou úpravu přináší české právo, které vychází z tohoto rámce.

Z hlediska mezinárodního hraje významnou roli Mezinárodní agentura pro atomovou energii. Tato agentura vypracovává doporučení pro členské země v oblastech atomového práva, mezi která patří i doporučení a standardy pro zvládání mimorádných radiačních událostí.

\section{POUŽITÉ PRAMENY}

\section{Internetové zdroje}

Convention on Assistance in the Case of Nuclear Accident or Radiological Emergency. In: International Atomic Energy Agency [online]. [cit. 14. 7 2019]. Dostupné z <https:// www.iaea.org/topics/nuclear-safety-conventions/ convention-assistance-case-nuclear-accident-or-radio logical-emergency>

CKD. IAEA. In: Euroskop [online]. Září 2018 [cit. 14. 7 2019]. Dostupné z <https://www.euroskop.cz/9137/sekce/iaea/> Emergency preparedness and response. In: International Atomic Energy Agency [online]. [cit. 14. 7 2019]. Dostupné z: <https://www.iaea.org/topics/emergency-preparedness -and-response-epr>

Evropské společenství pro atomovou energii - Euratom. In: Státní úrad pro jadernou bezpečnost [online]. [cit. 14. 7 2019]. Dostupné z <https://www.sujb.cz/evropska-unie/ 
evropske-spolecenstvi-pro-atomovou-energii-euratom/> Jaderné havárie. In: Jaderné elektrárny [online]. [cit. 14. 7 2019]. Dostupné z: <https://www.jaderne-elektrarny.cz/ jaderna-havarie/>

Smlouva o Euratomu. In: Státní úrad pro jadernou bezpečnost [online]. [cit. 14. 7 2019]. Dostupné z <https://www.sujb. cz/evropska-unie/smlouva-o-euratomu-a-sekundarni -pravni-predpisy/smlouva-o-euratomu/>

Vnější havarijní plán jaderné elektrárny Temelín. In: Hasičský záchranný sbor České republiky [online]. [cit. 14. 7 2019]. Dostupné z: <https://www.hzscr.cz/clanek/vnejsi-havarijni -plan-jaderne-elektrarny-temelin.aspx>

Výpis z vnějšího havarijního plánu pro zónu havarijního plánování JE Dukovany. In: Oficiální internetové stránky Kraje Vysočina [online]. 11. 2. 2005 [cit. 14. 7 2019]. Dostupné z: <https://www.kr-vysocina.cz/vypis-z-vnejsiho-havarijniho -planu-pro-zonu-havarijniho-planovani-je-dukovany/ d-854177>

\section{Technické normy}

Základní informace pro připad radiační havárie jaderné elektrárny Temelín 2018-2019. Zpracoval: Útvar havarijní připravenosti ČEZ, a. s., a Útvar komunikace ETE ČEZ, a. s. Obsah byl schválen SÚJB, hejtmanem Jihočeského kraje a HZS Jihočeského kraje.

Státní úřad pro jadernou bezpečnost. INES, mezinárodní stupnice hodnocení závažnosti jaderných a radiačních událostí, uživatelská příručka. Překlad INES: The International Nuclear and Radiological Event Scale User's Manual. Překlad vydán roku 2016. Připraveno v SÚJB. 
Radiační havárie jaderné elektrárny v České republice / Lucie Knödlová

\section{Právní úprava}

Ústavní zákon č. 110/1998 Sb., o bezpečnosti České republiky. Zákon č. 240/2000 Sb., o krizovém řízení a o změně některých zákonů (krizový zákon).

Zákon č. 239/2000 Sb., o integrovaném záchranném systému. Vyhláška č. 359/2016 Sb., o podrobnostech k zajištění zvládání radiační mimořádné události. Směrnice Rady 2013/59/EURATOM. 
Radiační havárie jaderné elektrárny v České republice / Lucie Knödlová

\section{Přílohy}

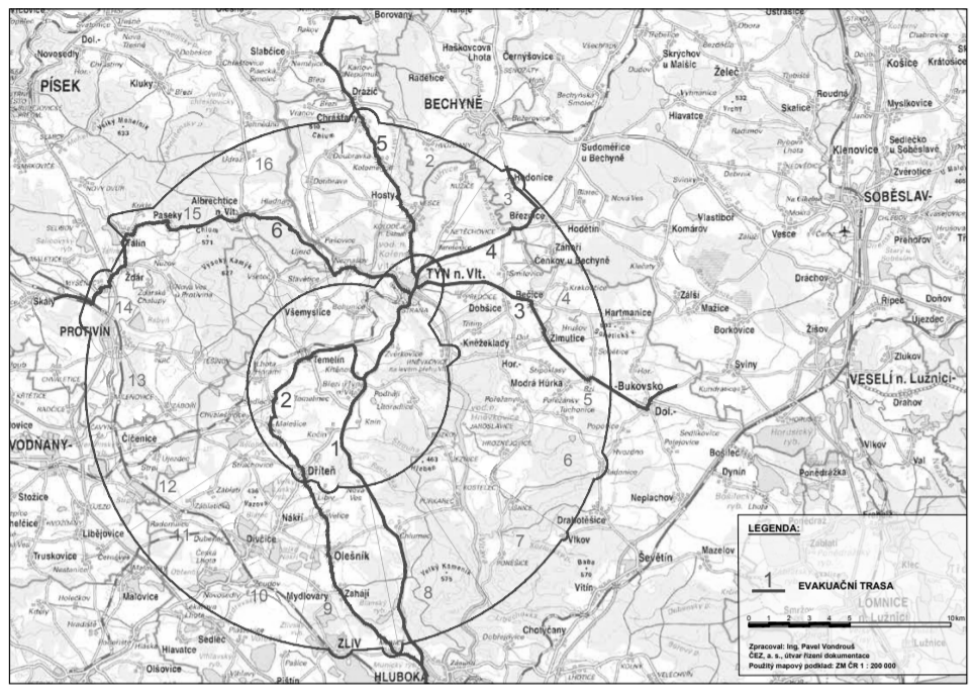

Obrázek č. 1: Mapa zóny havarijního plánování JE Temelín

Zdroj: Základní informace pro případ radiační havárie jaderné elektrárny Temelín 2018-2019. Zpracoval: Útvar havarijní připravenosti ČEZ, a. s., a Útvar komunikace ETE ČEZ, a. s. Obsah byl schválen SÚJB, hejtmanem Jihočeského kraje a HZS Jihočeského kraje, staženo dne 14. 7. 2019 
Radiační havárie jaderné elektrárny $v$ České republice / Lucie Knödlová

\begin{tabular}{|c|c|c|c|}
\hline $\begin{array}{l}\text { Popis } \\
\text { a stupně INES }\end{array}$ & Obyvatelé a životní prostředí & $\begin{array}{c}\text { Radiační bariéry a opatření } \\
\text { v zařizení }\end{array}$ & Ochrana do hloubky \\
\hline $\begin{array}{l}\text { Velmi tôż̌ká havárie } \\
\text { Stupeñ } 7\end{array}$ & 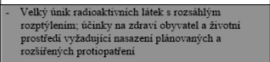 & & \\
\hline $\begin{array}{l}\text { Téžká havárie } \\
\text { Stupeñ } 6\end{array}$ & 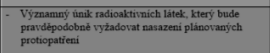 & & \\
\hline $\begin{array}{l}\text { Havárie s širšími } \\
\text { následky } \\
\text { Stupeñ } 5\end{array}$ & 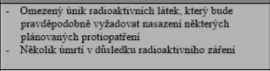 & 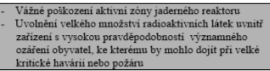 & \\
\hline $\begin{array}{l}\text { Havárie s mistnimi } \\
\text { následky } \\
\text { Stupeñ } 4\end{array}$ & 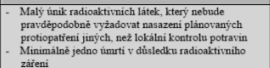 & 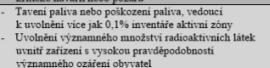 & \\
\hline $\begin{array}{l}\text { Vážná nehoda } \\
\text { Stupeñ } 3\end{array}$ & 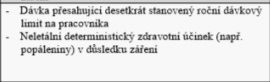 & 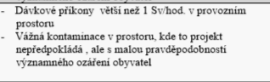 & 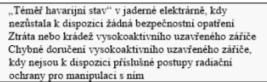 \\
\hline $\begin{array}{l}\text { Nehoda } \\
\text { Stupeñ } 2\end{array}$ & 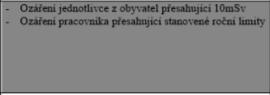 & 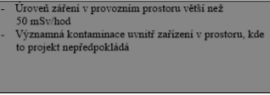 & 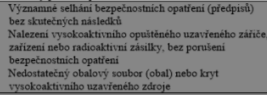 \\
\hline $\begin{array}{l}\text { Anomálie } \\
\text { Stupeñ } 1\end{array}$ & & & 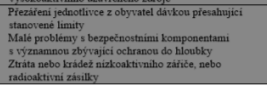 \\
\hline
\end{tabular}

Obrázek č. 2: Obecná kritéria pro hodnocení událostí v INES

Zdroj: Státní úřad pro jadernou bezpečnost. INES, mezinárodní stupnice hodnocení závažnosti jaderných a radiačních událostí, uživatelská příručka. Překlad INES: The International Nuclear and Radiological Event Scale User's Manual. Překlad vydán roku 2016. Připraveno v SúJB, s. 16, staženo dne 14. 7. 2019 